\title{
FACTORS THAT INFLUENCE THE LENGTH OF HOSPITALIZATION FOR ACUTE HEART FAILURE PATIENTS IN RSUP DR. M DJAMIL
}

\author{
M. Syaoqi ${ }^{1 *}$, Andri ${ }^{1}$, Citra Kiki Krevani ${ }^{2}$, Muhammad Syukri ${ }^{2}$ \\ ${ }^{1}$ Dep. Ilmu Penyakit Jantung dan Pembuluh Darah, Fakultas Kedokteran, Universitas Andalas, Indonesia \\ ${ }^{2}$ Divisi Kardiologi dan Kedokteran Vaskular, RSUP Dr. M. Djamil, Indonesia
}

*Corrrespondence email : msyaoqi140186@gmail.com

\begin{abstract}
More than 500,000 new patients were diagnosed with heart failure each year in all developing countries. Previous studies had shown that longer hospitalizations for patients with acute heart failure are associated with worse outcome. We analysed factors that influence length of hospitalization in our centre. We used a retrospective and descriptive analysis of acute heart failure patients at RSUP DR. M. Djamil from January to March 2018. We collected patient data from medical records including baseline characteristics, laboratory and echocardiographic results. We used statistical analysis to find the average length of stay (LOS) and possible causes of longer hospitalization. Among 30 patients had been collected, mean LOS was 6.23 days. Mean for age, BMI, and LVEF were 59.87 years, $23.55 \mathrm{~kg} / \mathrm{m}^{2}$, and $36.93 \%$, respectively. Patients having LOS $>6$ days may have relationship with initial degree edema pretibial $(\mathrm{p}=0.025)$ and systolic BP below $120 \mathrm{mmHg}$ $(\mathrm{p}=0.018)$, but no significant with rales $(\mathrm{p}=0.543)$ and pulmonary infection $(\mathrm{p}=0.709)$. Length of stay associated with the degree of pretibial pitting edema and systolic blood pressure at admission.
\end{abstract}

Keywords: Acute Heart Failure; Length of Stay; Pitting Edema Pretibial

\section{INTRODUCTION}

Heart failure (HF) is accountable for about 1 million admissions in all hospitals in the United States and costs around 37.2 billion of US dollars. ${ }^{1}$ In the developing countries, there are 500,000 new patients with the diagnoses of HF. In 2006 there were 1687 admissions of patients with the diagnosis of acute decompensated heart failure at 5 Indonesian hospitals including Rumah Sakit Jantung dan Pembuluh Darah Harapan Kita (RSJPHK). ${ }^{2}$

Several studies show that the length of stay in acute HF patients is associated with poorer prognosis and is considered a separate economic problem, where those studies generally examine HF patients with reduced ejection fraction. ${ }^{4}$ One study stated the proportion of acute HF patients that being hospitalized consist of $80 \%$ worsened chronic HF patients, $15 \%$ de novo HF patients, and the rest were advanced HF patients. ${ }^{1}$ In this study, we determined the average length of stay and the factors that influence the length of stay in patients with acute HF in RSUP dr. M. Djamil West Sumatra - Padang.

\section{MATERIAL AND METHODS}

This study used retrospective and descriptive analysis on the data of the treated acute HF patients starting in January 2018 - March 2018 in intensive cardiology care unit and the cardiac high intensive care unit of RSUP Dr. M. Djamil West Sumatera - Padang. It has been recorded with the amount of 37 acute HF patients. The collected patient data were obtained from the medical records including basic data, laboratory results and echocardiography results. We noted several factors of the patient's clinical status including comorbidities that appear in the Emergency Room (ER). Patients without echocardiographic data or death were excluded from this analysis.

The pretibial pitting oedema is divided into 2 groups, the +1 degree as the first group and the degree of more than +1 as the second group. The degree of pretibial pitting 
oedema is adjusted by the explanation from a certain book. ${ }^{5}$ Rhonchi in the lungs is divided into 2 groups, namely bi basal rhonchi and the advance bi basal rhonchi. The diagnosis of patient's comorbidities were adjusted to the prevailing guidelines.

Statistical analysis was conducted with SPSS 15.0 with a descriptive method to obtain the average results and standard deviation on the basic data and the duration of the patient's stay. The $\chi^{2}$ analysis (Chi-square) was used to test the difference of two patient group averages between the longer and the shorter length of stay.

\section{RESULTS}

Among 30 patients included in the inclusion criteria, $66.67 \%$ were males aged around 59 years. It appears in Table 1, 60\% of patients were having hypertension, and only $20 \%$ having diabetes. Around $76.67 \%$ of the patients have a history of ischemic coronary heart disease.

Table 1. Basic characteristics

\begin{tabular}{lc}
\hline \multicolumn{1}{c}{ Basic Data } & Score \\
\hline Age (Year, M \pm SD) & $59.87 \pm 9.723$ \\
\hline Male $(\%)$ & $66.67 \%(20 / 30)$ \\
\hline $\begin{array}{l}\text { BMI during admission } \\
(\mathrm{kg} / \mathrm{m} 2, \mathrm{M} \pm \mathrm{SD})\end{array}$ & $23.39 \pm 3.80$ \\
\hline Hypertension $(\%)$ & $60.00 \%(18 / 30)$ \\
\hline Diabetes mellitus $(\%)$ & $20.00 \%(6 / 30)$ \\
\hline $\begin{array}{l}\text { Ischaemic heart disease } \\
(\%)\end{array}$ & $76.67 \%(23 / 30)$ \\
\hline $\begin{array}{l}\text { SBP during admission } \\
(\mathrm{mmHg}, \mathrm{M} \pm \mathrm{SD})\end{array}$ & $124.07 \pm 26.38$ \\
\hline $\begin{array}{l}\text { Respiratory rate during } \\
\text { admission (time/min, } \\
\mathrm{M} \pm \mathrm{SD})\end{array}$ & $29.33 \pm 5.12$ \\
\hline $\begin{array}{l}\text { Heart rate during } \\
\text { admission (beats/min, } \\
\mathrm{M} \pm \mathrm{SD})\end{array}$ & $104.83 \pm 26.45$ \\
\hline Leucocyte/mm3 (M $\pm \mathrm{SD})$ & $14102.67 \pm 5121.91$ \\
\hline Hb (mg/dL, M $\pm \mathrm{SD})$ & $12.93 \pm 2.01$ \\
\hline $\begin{array}{l}\text { Serum urea }(\mathrm{mg} / \mathrm{dL}, \\
\mathrm{M} \pm \mathrm{SD})\end{array}$ & $46.53 \pm 32.89$ \\
\hline $\begin{array}{l}\text { Serum creatinine } \\
(\mathrm{mg} / \mathrm{dL}, \mathrm{M} \pm \mathrm{SD})\end{array}$ & $1.49 \pm 0.70$ \\
\hline $\begin{array}{l}\text { Left ventricle ejection } \\
\text { fraction }(\%, \mathrm{M} \pm \mathrm{SD})\end{array}$ & $36,93 \pm 9,570 \%$ \\
\hline
\end{tabular}

During the initial assessment in the emergency room, the vital signs obtained were the systolic blood pressure of $124.07 \pm$ $26.38 \mathrm{mmHg}$, with pulse rate of $104.83 \pm$ 26.45 times/minute, respiratory rate $29.33 \pm$ 5.12 time/minute, and there was no fever complaint reported. Average number of leukocytes of $14,102.67 \pm 5.121,91 / \mathrm{mm} 3$, with haemoglobin range of $12.93 \pm 2.01$ $\mathrm{mg} / \mathrm{dL}$. Serum urea Average examination of $46.53 \pm 32.89 \mathrm{mg} / \mathrm{dL}$ and creatinine serum of $1.49 \pm 0.70 \mathrm{mg} / \mathrm{dL}$ for kidney function. Left ventricular ejection fraction in patients is entirely $<50 \%$ with the average of 36.93 $\pm 9.570 \%$.

Coming out of the 30 patients studied, the average length of stay is 6.23 days. Figure 1 shows patients with systolic blood pressure $<120 \mathrm{mmHg}$ during the initial examination tends to be treated for $>6$ days $(\mathrm{P}=0.018)$. But it does not affect the pulse rate $(\mathrm{P}=0.136)$ as shown in Figure 2 . The patient's body temperature is entirely normal during the admission, so there was no statistical treatment being given.

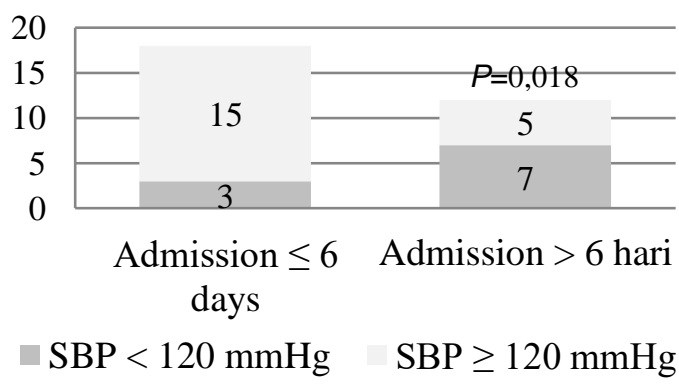

Figure 1. Initial systolic blood pressure

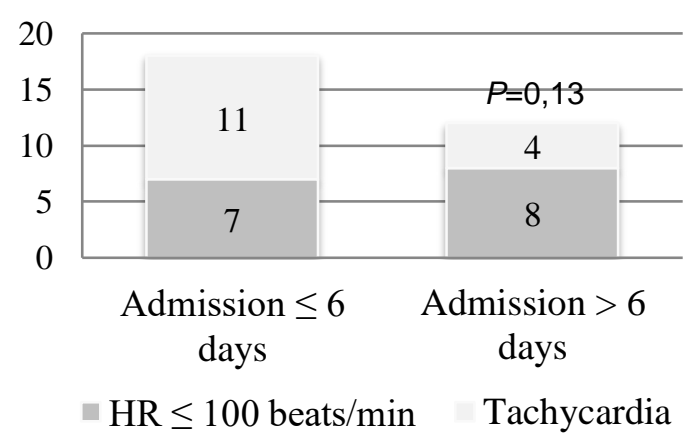

Figure 2. Initial heart rate 
Figure 3 shows the patient with the degree of $\geq+2$ pretibial pitting edema, have exceeds the average length of stay for 6 days $(\mathrm{P}=$ $0.025)$. On the contrary patients with a degree of more than bi basal pulmonary rhonchi, apparently does not affect the duration of treatment $(\mathrm{P}=0,543)$. The value of leukocytes and creatinine in the serum also does not affect the duration of treatment $(\mathrm{P}=0,290$ and $\mathrm{P}=$ 0,654 , respectively).

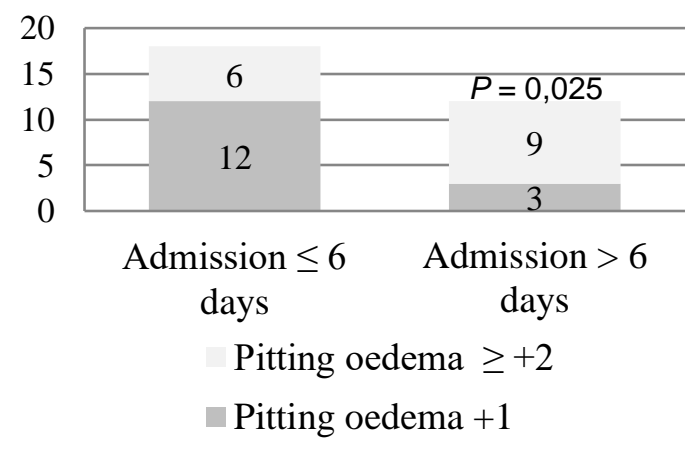

Figure 3. Initial pitting edema degree

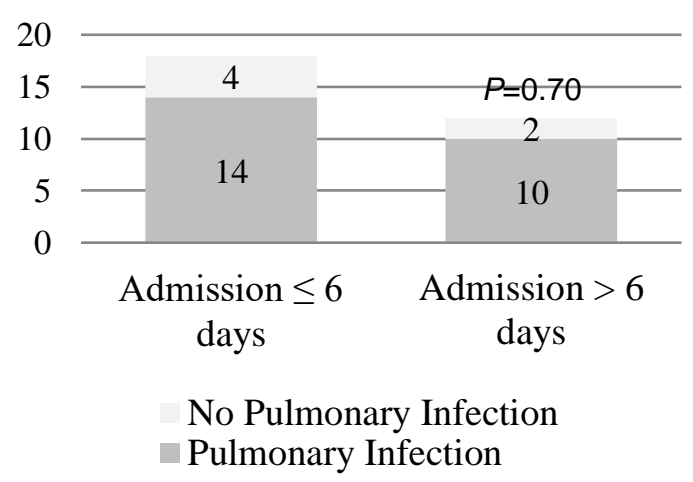

Figure 4. Pulmonary infection as comorbidity

Shown in Figure 4, lung infections are not significantly influence the duration of treatment $(P=0.709)$, whereas other comorbid only have minimum amount, so the statistical analysis is not performed.

\section{DISCUSSION}

This study obtained the average length of hospitalization for patients with acute HF in our centre was still faster compared to the other studies in Indonesia. ${ }^{6}$ Dyah S. E. et al received an average stay of patient with congestive HF in RSUD Arifin Achmad for 7.29 days. Considering a study at RSCM in 2012, the median length of inpatient hospital in $\mathrm{HF}$ patients was $8-9$ days. Compared to ESCAPE studies, our study was much shorter in terms of the duration of the treatment. ${ }^{4}$

On this study, we gained the proportion of male patients as much as $66.67 \%$ with the average age of 59 years. These results still show similarities to other studies where males are more dominant. H.R. Omar et al stated that males were as much as $74 \%$ and the average age of all patients was 56 years on his study from the ESCAPE data register. ${ }^{4}$ In Indonesia that value was also nearly the same as it is in RSPAD Gatot Soebroto on 2010, the obtained were close to those value $(72.7 \%)$ For male patients. In 2012, 62,2\% HF patients who were treated in RSCM were males with the median age of 58 years. 6 According to AHA (American Heart Association), around $75 \%$ of patients with heart failure suffer from hypertension. ${ }^{8}$ The long and uncontrolled hypertension was associated with systolic and diastolic failures on heart failure. Even a mild reduction of systolic blood pressure reduces the risk of mortality and the risk of heart failure. ${ }^{9}$

Acute $\mathrm{HF}$ patients with $\leq 120 \mathrm{mmHg}$ of systolic blood pressure on the initial treatment on this study may have a prolonged hospitalization. Thus far the author has not yet found any other study linking early blood pressure examinations with prolonged treatment in patients with acute heart failure. As it is known, hypertension is one of the most common risk factors for heart failure.

The degree of pretibial oedema for $\geq+$ 2 is related to the duration of treatment in this study. The study by Wright, S. P. et al stated that the duration of treatment was associated with peripheral congestion (pretibial oedema), duration of diuretics treatment, and other acute illness during the admission in New Zealand. ${ }^{10}$ In addition, that study also revealed that the degree of wet-rhonchi in patients is not related to the increasing length of hospitalization, in line with the results of this study. ${ }^{10}$ The higher 
degrees of pitting oedema in patients takes extra time in the treatment of intravenous diuretics to increase the mobility of $\mathrm{HF}$ regarding to increase their quality of life.

Pulmonary infection as the most common comorbid for patients in this study shows no effect to the duration of treatment. This may be due to an aggressive management that optimize the management of this disease. As it is known, pulmonary infection is one of the risk factors for higher mortality rates in acute HF patients in the treatment. ${ }^{11}$ But this patient's data does not include patients who died because we did not measure the mortality rate in this study.

\section{CONCLUSION}

The average length of treatment for acute heart failure patients in RSUP Dr. M. Djamil is 6.23 days. Longer treatments related to the degree of pretibial pitting oedema and systolic blood pressure during initial examination in the hospitals.

\section{REFERENCES}

1. Gheorghiade M, Vaduganathan M, Fonarow GC, Bonow RO. Rehospitalization for Heart Failure: Problems and Perspectives. Journal of the American College of Cardiology. 2013;61(4):391-403.

2. Siswanto BB, Radi B, Kalim H, Santoso A, Suryawan R, et al. Heart failure in NCVC Jakarta and 5 hospitals in Indonesia. CVD Prevention and Control. 2010;5:35-8.

3. Chun S, Tu JV, Wijeysundera HC, Austin PC, Wang X, et al. Lifetime Analysis of Hospitalizations and Survival of Patients Newly Admitted with Heart Failure. Circulation Heart Failure. 2012;5(4):414-21.

4. Omar HR, Guglin M. Longer-than-average Length of Stay in Acute Heart Failure. Springer. 2018;43(2):131-9.

5. Bickley LS, Szilagyi PG. Bates' Guide to Physical Examination and History Taking. 12th ed. Philadelphia, PA: Wolters Kluwer; 2017.p528-9.

6. Djaya KH, Nasution SA, Antono D. Gambaran Lama Rawat dan Profil Pasien Gagal Jantung di Rumah Sakit Cipto Mangunkusumo. Indonesian Journal of
Chest: Critical and Emergency Medicine. 2015;2(4):141-9.

7. Darmawan W, Doddy D. Hubungan umur, jenis kelamin, dan riwayat hipertensi dengan angka kejadian gagal jantung kongestif di poli jantung RSPAD Gatot Soebroto Periode 1 Juli 2010 - 31 Desember 2010. Bachelor of Medicine [undergraduate thesis]. Jakarta: Pembangunan Nasional Veteran University; 2010.

8. Lloyd-Jones D, Adams RJ, Brown TM, Carnethon M, Dai S, et al. Heart Disease and Stroke Statistics-2010 Update a Report from the American Heart Association. Circulation. 2010;121:e46-e215.

9. Sleight P. The HOPE Study (Heart Outcomes Prevention Evaluation). Journal of The Renin-AngiotensinAldosterone System. 2001;1(1):18-20.

10. Wright SP, Verouhis D, Gamble G, Swedberg K, Sharpe N, et al. Factors influencing the length of hospital stay of patients with heart failure. The European Journal of Heart Failure. 2003;5:201-9.

11. Cardoso JN, Carlo CHD, Junior MTdO, Ochiai ME, Filho RK, et al. Infection in Patients with Decompensated Heart Failure: In-Hospital Mortality and Outcome. Arquivos Brasileiros de Cardiologica. 2018;110(4):364-70. 